\title{
PENGARUH PENYULUHAN PERTANIAN DALAM ASPEK LINGKUNGAN, EKONOMI DAN TEKNOLOGI PADA PETANI PADI SAWAH DI KECAMATAN MODAYAG
}

\author{
Sopiyan Hasan \\ Wenny Tilaar \\ Lientje Theffie Karamoy
}

\begin{abstract}
The purpose of this study was to analyze whether the Environmental Aspects influencing on rice production in Sub-district of Modayag, to analyze whether the Economics aspect affect on of rice production in Sub-district Modayag and to analyze whether the effect of the technology aspects on rice production in Sub-district of Modayag. The research was conducted on a group of Paddy Rice Farmers in the Sub-district of Modayag, East Mongondow Bolaang District, in March 2015 until December 2016. The colection of primary data conducted after the agricultural extension officer held the extension in January 2016. The study lasted approximately 1 year to examine the changes in the knowledge, skills and attitudes of paddy rice farmers. Retrieving data using questionnaires to 30 (thirty) of respondents from Rice farmers in Sub-district of Modayag. From this study it can be concluded that the extension of an underlying process on Environmental Aspects, Economics and Technology Aspects effect on changes in knowledge, skills and attitudes of paddy farmers in the Sub-district of Modayag. The third aspect of the existing namely Environmental Aspects, Economics and Technology Aspects of the most influential in the process of agricultural extension is Economics.
\end{abstract}

Key words: Agricultural extension officers; aspect of environment, economic and technology; farmers of paddy rice, the Subdistrict of Modayag, East Mongondow Bolaang District

\section{ABSTRAK}

Tujuan penelitian ini adalah untuk menganalisis apakah Aspek Lingkungan berpengaruh pada produksi padi sawah di Kecamatan Modayag, untuk menganalisis apakah Aspek Ekonomi berpengaruh pada produksi padi sawah di Kecamatan Modayag dan untuk menganalisis apakah Aspek Teknologi berpengaruh pada produksi padi sawah di Kecamatan Modayag. Penelitian ini dilaksanakan pada kelompok Tani Padi Sawah di Kecamatan Modayag Kabupaten Bolaang Mongondow Timur, pada bulan Maret 2015 sampai dengan Desember 2016. Pengambilan data primer dilakukan sesudah pelaksanaan penyuluhan pada bulan Januari 2016. Penelitian ini berlangsung kurang lebih 1 tahun untuk melihat perubahan pengetahuan, keterampilan dan sikap dari petani padi sawah yang ada di Kecamatan Modayag. Pengumpulan data dengan menggunakan kuesioner kepada 30 (tiga puluh) responden petani Padi Sawah di Kecamatan Modayag. Dari penelitian ini dapat di simpulkan bahwa Proses penyuluhan yang di dasari pada Aspek Lingkungan, Aspek Ekonomi dan Aspek Teknologi berpengaruh pada perubahan pengetahuan keterampilan dan sikap petani padi sawah di Kecamatan Modayag. Dari ketiga Aspek yang ada yaitu Aspek Lingkungan, Aspek Ekonomi dan Aspek Teknologi yang paling berpengaruh dalam proses penyuluhan pertanian yaitu Aspek Ekonomi.

Kata kunci: Penyuluh, Pertanian, Aspek Lingkungan, Aspek Ekonomi, Aspek Teknologi, Kecamatan Modayag Kabupaten Bolaang Mongondow Timur 


\section{PENDAHULUAN}

$\begin{array}{lrrr}\text { Negara } & \text { Indonesia } & \text { merupakan } & \text { Negara } \\ \text { agraris yang } & \text { artinya } & \text { sebagian } & \text { besar } \\ \text { penduduknya } & \text { berprofesi } & \text { sebagai } & \text { petani. }\end{array}$
Banyaknya jumlah penduduk Indonesia yang menggantungkan hidupnya dari sektor pertanian menunjukan demikan besar peranan sektor pertanian dalam menopang perekonomian dan memiliki implikasi penting dalam pembangunan ekonomi ke depan. Namun, Pembangunan pertanian dinegara kita masih terkendala oleh banyak factor yang menyebabkan sulitnya bagi para petani padi sawah untuk berkembang, oleh karena itu dibutuhkan fasilitator yang dilakukan oleh pekerja pengembangan masyarakat antara lain sebagai orang yang mampu mendengar dan memahami aspirasi masyarakat,sertamampu memberikan dukungan berupa informasi teknologi dalam bidang pertanian.

Penyuluhan pertanian bertujuan untuk meningkatkan pengetahuan dan keterampilan serta merubah sikap dan perilaku petani beserta keluarganya dari tradisonal menjadi dinamis rasional dengan cara memberikan penyuluhan tentang bahaya Pestisida dan Pupuk kimia pada Lingkungan sekitar.Penyuluhan pertanian berperan penting bagi pembangunan pertanian, sebab penyuluhan merupakan salah satu upaya pemberdayaan petani dan pelaku usaha pertanian lain untuk meningkatkan produktifitas, pendapatan dan kesejahteraan tanpa mengesampingkan kelestarian Lingkungan. Oleh karena itu kegiatan penyuluhan pertanian harus dapat mengakomodasikan aspirasi dan peran aktif petani dan pelaku usaha pertanian lainya melalui pendekatan partisipatif.

Penyuluhan pertanian merupakan pendidikan non formal bagi petani beserta keluarganya yang meliputi kegiatan dalam ahli pengetahuan dan keterampilan dari penyuluh lapangan kepada petani dan keluarganya berlangsung melalui proses belajar mengajar. Penyuluh pertanian harus ahli pertanian yang berkompeten, disamping bisa berkornunikasi secara, efektif dengan petani sehingga dapat mendorong minat belajar mereka dan harus berorientasi pada masalah yang dihadapi oleh petani (Mardikanto, 2009).
Petani adalah pelaku utama dalam kegiatan produksi pertanian serta bagian dari masyarakat Indonesia yang perlu ditingkatkan kesejahteraan dan kecerdasannya, salah satu upaya peningkatan kecerdasan tersebut dilaksanakan melalui kegiatan penyuluhan. Dengan adanya penyuluhan diharapkan semua informasi pertanian yang berkembang dapat diserap dan diterima oleh petani, semakin banyak informasi yang dimanfaatkan oleh petani maka semakin efektif penyuluhan tersebut.

Peletarian berwawasan lingkungan adalah usaha peningkatan kualitas Manusia secara bertahap dengan memperhatikan faktor lingkungan. Pelestarian lingkungan merupakan kebutuhan yang tidak bisa ditunda lagi dan bukan hanya menjadi tanggung jawab pemerintah, melainkan tanggungjawab setiap insan di Bumi, setiap orang harus melakukan usaha untuk menyelamatkan lingkungan hidup di sekitar kita sesuai dengan kapasitas kita masing-masing. Sekecil apapun usaha yang kita lakukan sangat bermanfaat bagi terwujudnya Bumi yang layak huni bagi kelangsungan generasi anak cucu kita kelak (Sumarno, 2006)

Di Kecamatan Modayag pemanfaatan lahan pertanian didominasi oleh tanaman Hortikultura dan tanaman pangan khususnya komoditas tanaman padi yang terbentuk dalam kelompok-kelompok tani. Peranan Penyuluh Pertanian di Kecamatan ini sangat dibutuhkan untuk usaha budidaya tanaman Hortikultura dan tanaman pangan dengan memperhatikan kelestarian lingkungan. Untuk mewujudkan semua itu penyuluh pertanian harus lebih maksimal dalam memberikan penyuluhan tentang bahaya pestisida dan pupuk kimia dalam lingkungan pertanian sekitar khusnya lahan padi sawah. Memang disadari bahwa penyuluhan pertanian mengalami keterpurukan setelah pengelolaan penyuluh dilimpahkan kepada pemerintah daerah, pola pengawasan dan pembinaan penyuluh terabaikan yang menyebabkan kinerja penyuluh menurun tajam. Pada tanggal 11 Juni 2005 Presiden RI mencanangkan Revitalisasi Pertanian Perikanan dan Kehutanan (RPPK) di Jatiluhur, Provinsi Jawa Barat, sebagai Triple Track Strategi Kabinet Indonesia Bersatu dalam rangka pengurangan kemiskinan dan pengangguran 
serta peningkatan daya saing ekonomi nasional dan menjaga kelestarian sumber daya pertanian, perikanan dan kehutanan (Menteri Pertanian Republik Indonesia, 2007).

Mengingat peranannya sebagai pemegang kunci keberhasilan, maka penyelenggaraan penyuluhan pertanian terutama di daerah-daerah yang berpotensi sebagai penghasil tanaman pangan sangat perlu dilakukan dan harus mendapatkan perhatian, khususnya pemerintah daerah. Hal tersebut dilakukan untuk menciptakan suatu perubahan tingkah laku petani menuju ke arah perbaikan usahatani yang selanjutnya akan berdampak pada peningkatan produktivitas, pendapatan, dan kesejahteraan keluarga petani. Apabila keadaan demikian berjalan dengan baik, maka potensi yang terkandung di daerah tersebut dapat diwujudkan sebagai suatu realitas yang terus bertahan sebagai benteng ketahanan pangan daerah maupun nasional.

Kecamatan Modayag merupakan kecamatan yang memiliki jumlah desa terbanyak di Kabupaten Bolaang Mongondow Timur yaitu sejumlah 24 Desa dan 13 Desa diantaranya memiliki lahan persawahan. Kecamatan Modayag terletak Ketinggian 600 m dari permukaan laut. Jarak Ibukota Kecamatan ke Ibukota Kabupaten sejauh $55 \mathrm{Km}$ kearah Timur.

Adapun batas-batas wilayah Kecamatan Modayag meliputi :

Sebelah Utara : Kecamatan Passi Timur Kab. Bolaang Mongondow

Sebelah Selatan : Kecamatan Nuangan Sebelah Barat : Kecamatan Modayag Barat Sebelah Timur : Kecamatan Modoinding Kab. Minahasa Selatan
Luas Wilayah Kecamatan Modayag adalah 21.901,909 Ha. Dengan luas persawahan $479 \mathrm{Ha}$. Tersedianya lahan pertanian yang luas di Kecamatan Modayag merupakan salah satu faktor pendukung perkembangan sektor pertanian di Kecamatan Modayag. Untuk tanaman padi, Kecamatan Modayag merupakan sentra produksi padi dan lumbung gabah Kabupaten Bolaang Mongondow Timur karena produktivitas padi Kecamatan Modayag paling tinggi apabila dibandingkan dengan kecamatankecamatan lainnya di Kabupaten Bolaang Mongondow Timur. Dapat dilihat pada Tabel 1. Luas Tanam Menurut Komoditas Di Kecamatan Modayag.

Balai Penyuluhan Pertanian Perikanan
dan Kehutanan Kecamatan Modayag
merupakan salah satu kelembagaan penyuluhan
pertanian di Kabupaten Bolaang Mongondow
Timur. Dengan jumlah desa di wilayah BP3K
Kecamatan Modayag yaitu sebanyak 24 desa.
Kelembagaan pelaku utama yang ada di
Kecamatan Modayag terdiri atas 138 kelompok
tani, yang terdiri dari 96 Kelompok Tani
Pemula, 30 Kelompok Tani Lanjut, 12
Kelompok Tani Madya. Selain kelompok tani,
di Kecamatan Modayag juga telahterbentuk 22
Gapoktan. Dari 24 Desa yang ada dibagi
menjadi 9 wilayah binaan (wibi) penyuluh
pertanian di mana masing-masing wilayah
binaan terdiri atas 2 (dua) hingga 5 (lima) desa.
Masing-masing wilayah binaan dibawahioleh
satu orang penyuluh pertanian. Informasi
tentang Penyuluh Pertanian yang ada di BP3K
Kecamatan Modayag terdapat pada Tabel 2.
merupakan salah satu kelembagaan penyuluhan pertanian di Kabupaten Bolaang Mongondow Timur. Dengan jumlah desa di wilayah BP3K Kecamatan Modayag yaitu sebanyak 24 desa. Kelembagaan pelaku utama yang ada di Kecamatan Modayag terdiri atas 138 kelompok tani, yang terdiri dari 96 Kelompok Tani Pemula, 30 Kelompok Tani Lanjut, 12 Kelompok Tani Madya. Selain kelompok tani, di Kecamatan Modayag juga telahterbentuk 22 Gapoktan. Dari 24 Desa yang ada dibagi menjadi 9 wilayah binaan (wibi) penyuluh pertanian di mana masing-masing wilayah binaan terdiri atas 2 (dua) hingga 5 (lima) desa. Masing-masing wilayah binaan dibawahioleh satu orang penyuluh pertanian. Informasi Kecamatan Modayag terdapat pada Tabel 2.

Tabel 1. Luas Tanam Menurut Komoditas Di Kecamatan Modayag

\begin{tabular}{lccc}
\hline \multicolumn{1}{c}{ Jenis Tanaman } & $\begin{array}{c}\text { Rumah } \\
\text { Tangga }\end{array}$ & Luas Tanam $\left(\mathbf{M}^{\mathbf{2})}\right.$ & $\begin{array}{c}\text { Rata-rata Luas Tanam } \\
\left(\mathbf{M}^{\mathbf{2}}\right)\end{array}$ \\
\hline - Padi Sawah & 444 & 5.970 .591 & $13.386,98$ \\
- Jagung & 196 & 1.703 .318 & $8.690,40$ \\
- Ubi Kayu & 71 & 102.254 & $1.440,20$ \\
- Kacang Tanah & 50 & 181.012 & $3.620,24$ \\
- Kedelai & 3 & 44.000 & $14.666,67$ \\
\hline
\end{tabular}

Sumber Data : Badan Pusat Statistik Kota Kotamobagu 2015 
Tabel 2. Daftar Nominatif Penyuluh Pertanian BP3K Modayag

\begin{tabular}{|c|c|c|c|c|c|}
\hline \multirow{2}{*}{ No. } & \multirow[t]{2}{*}{ Nama } & \multirow{2}{*}{$\mathrm{L} / \mathrm{P}$} & \multicolumn{2}{|l|}{ Pendidikan Terakhir } & \multirow[t]{2}{*}{ Wilayah Binaan } \\
\hline & & & Tingkat Pendidikan & Thn. Lulus & \\
\hline 1 & Amru Damopolii, S. Pt & $\mathrm{L}$ & $\begin{array}{c}\text { S1 Peternakan (Nutrisi dan Makanan } \\
\text { Ternak) }\end{array}$ & 1998 & Koordinator \\
\hline 2 & Andi S. Tontoigon, SP & $\mathrm{L}$ & S1 Pertanian (Ilmu Tanah) & 2000 & $\begin{array}{c}\text {-Bongkudai Selatan } \\
\text {-Mooat } \\
\end{array}$ \\
\hline 3 & Sopiyan Hasan, SP & $\mathrm{L}$ & S1 Pertanian (Budidaya Pertanian) & 2009 & $\begin{array}{l}\text {-Bongkudai Baru } \\
\text {-Bongkudai Timur } \\
\text {-Bongkudai Utara } \\
\text {-Purworejo Timur }\end{array}$ \\
\hline 4 & Sariyati Osang, SP & $\mathrm{P}$ & S1 Pertanian (Ilmu Tanah) & 1999 & $\begin{array}{c}\text {-Modayag III Purworejo } \\
\text {-Sumber Rejo } \\
\end{array}$ \\
\hline 5 & Ihlan Pontoh, SP & $\mathrm{L}$ & S1 Pertanian (Budidaya Pertanian) & 2013 & $\begin{array}{c}\text {-Tobongon } \\
\text {-Badaro } \\
\text {-Lanud } \\
\text {-Buyandi } \\
\end{array}$ \\
\hline 6 & Cindra Mokoagow & $\mathrm{P}$ & SPP (Tanaman Pangan) & 1996 & $\begin{array}{c}\text {-Purworejo Tengah } \\
\text {-Liberia Timur } \\
\end{array}$ \\
\hline 7 & Suryanti Potabuga & $\mathrm{P}$ & $\begin{array}{c}\text { SMT Pertanian (Teknologi Hasil } \\
\text { Pertanian) }\end{array}$ & 1994 & $\begin{array}{c}\text {-Modayag } \\
\text {-Modayag } 2 \\
\end{array}$ \\
\hline 8 & Mulfandri Ngodu & $\mathrm{L}$ & SMT Pertanian (Agronomi) & 1996 & $\begin{array}{c}\text {-Kokapoi } \\
\text {-Kokapoi Timur } \\
\text {-Guaan } \\
\text {-Mokitompia } \\
\text {-Mototompiaan } \\
\end{array}$ \\
\hline 9 & Hesminati Supit & $P$ & SPP (Hortikultura) & 2003 & $\begin{array}{c}\text {-Liberia } \\
\text {-Candi Rejo }\end{array}$ \\
\hline
\end{tabular}

\section{Rumusan Masalah}

1. Apakah Penyuluhan Pertanian tentang Aspek Lingkungan berpengaruh dalam peningkatan produksi Padi Sawah di Kecamatan Modayag ?

2. Apakah Penyuluhan Pertanian tentang Aspek Ekonomi berpengaruh dalam peningkatan produksi Padi Sawah di Kecamatan Modayag ?

3. Apakah Penyuluhan Pertanian tentang Aspek Teknologi berpengaruh dalam peningkatan produksi Padi Sawah di Kecamatan Modayag ?

\section{Tujuan Penelitian}

1. Untuk menganalisis apakan Aspek Lingkungan berpengaruh pada produksi Padi Sawah di Kecamatan Modayag.

2. Untuk menganalisis apakan Aspek Ekonomi berpengaruh pada produksi Padi Sawah di Kecamatan Modayag.

3. Untuk menganalisis apakan Aspek Teknologi berpengaruh pada produksi Padi Sawah di Kecamatan Modayag.

\section{Manfaat Penelitian}

1. Bagi peneliti,untuk menambah pengetahuan tentang penyelenggaraan penyuluhan pertanian secara langsung dari lapangan dan sebagai salah satu syarat untuk memperoleh gelar Magister Sains di Universitas Samratulangi Manado.

2. Bagi peneliti lain, dapat digunakan sebagai bahan pembanding dalam melakukan penelitian sejenis.

3. Bagi petani, sebagai sarana untuk meningkatkan kesadaran, akan pentingnya kelestarian lingkungan sebagai upaya memberdayakan petani untuk dapat meningkatkan produktivitas usaha tani, pendapatan, dan kesejahteraan keluarganya.

4. Bagi masyarakat umum, untuk memperluas dan memperbanyak khasanah ilmiah, keilmuan, penyuluhan pertanian, khususnya dalam bidang penyuluhan dan pengembangan sumberdaya manusia.

5. Bagi pengambil kebijakan yaitu Dinas Pertanian dan Badan Pelaksana Penyuluhan Pertanian, Perikanan, dan Kehutanan Kabupaten Bolaang Mongondow Timur sebagai pertimbangan dalam penentuan kebijakan pembangunan pertanian kedepan. 


\section{METODE PENELITIAN}

\section{Lokasi dan Waktu Penelitian}

Situasi yang didalamnya terdapat persoalan yang subtansif, teoritik dan terbuka untuk diteliti layak untuk dipilih menjadi tempat penelitian, (Afandi, 1993) Penelitian ini dilaksanakan pada kelompok Tani Padi sawah di Kecamatan Modayag Kabupaten Bolaang Mongondow Timur, pada bulan Maret 2015 sampai dengan Desember 2016. Pengambilan data Primer (kuisioner) sesuda penyuluhan pada bulan Januari 2016. Penelitian ini berlangsung kurang lebih 1 Tahun untuk melihat berubahan pengetahuan keterampilan dan sikap dari petani padi sawah yang ada di Kecamatan Modayag.

\section{Penentuan Sampel}

Maleong (2001) Jumlah sampel ditentukan oleh pertimbangan-pertimbangan informasi yang diperlukan. Jika maksudnya memperluas informasi, jika tidak ada lagi informasi yang tidak dapat dijaring maka penarikan sampelpun suda dapat diakhiri.Sampel yang diambil dalam penelitian ini yaitu petani padi sawah di Kecamatan Modayag dengan mengunakan Simple Random yaitu teknik pengambilan sampel secara acak sesuai krikteria yang telah ditentukan. Jumlah responden yang diambil yaitu sebanyak 30 (tiga puluh) responden yang tersebar di 13 Desa di Kecamatan Modayag yang mempunyai lahan persawahan produktif. Penarikan sampel diawali dengan survey terlebih dahulu untuk mengetahui kondisi dan lokasi pengambilan sampel.

\section{Jenis dan Sumber Data}

Penelitian ini menggunakan data primer dan data sekunder. Data primer adalah data yang diperoleh dari petani melalui wawancara dengan petani dengan menggunakan daftar pertanyaan (kuisioner). Data yang dibutuhkan tentang karakteristik petani meliputi Nama, umur, pendidikan, luas lahan, kepemilikan lahan pendapat petani tentang aspek ekonomi, aspek Teknologi dan aspek ekologi dalam proses penyuluhan pertanian. Adapun wawancara yang dilakukan yaitu dengancara terstruktur. Wawancara terstruktur, dalam hal ini dilakukan dengan cara sebelum wawancara terlebih dahulu disiapkan daftar pertanyaan sebagai panduan yang akan dijawab oleh responden pada lembaran jawaban yang telah disediakan. Moleong (2007) menjelaskan bahwa petujuk wawancara hanyalah berisi petunjuk secara garis besar tentang proses dan isi wawancara untuk menjaga agar pokokpokok yang direncanakan dapat seluruhnya tercakup.

Data sekunder yaitu data yang diperoleh dari berbagai sumber yaitu Diro pusat Statistik Kabupaten Bolaang Mongondow, Dinas Pertanian dan Peternakan Kabupaten Bolaang Mongondow Timur, BP4K Kabupaten Bolaang Mongondow Timur dan BP3K Kecamatan Modayag.

\section{Operasional Peubah}

Penerapan penyuluh

a. Aspek Lingkungan

1. Suhu

2. Kelembaban

3. Angin

4. Tanah

5. Cahaya

b. Aspek Ekonomi

1. Modal

2. Biaya Saprodi

3. Biaya Pengolahan

4. Biaya Panen dan Pasca Panen

c. Aspek Teknologi

1. Pestisida Nabati

2. Pupuk Organik

3. Sistem Tanam Jajar Legowo

a) Pendapat Petani

1. Peran Penyuluh

2. Manfaat Penyuluhan

Data dalam kuisioner dibuat dalam skala likert (Sugiono, 2000) dengan kriteria keadaan sebagai berikut :
a. Sangat Berpengaruh
$: 5$
b. Berpengaruh
$: 4$
c. Kurang Berpengaruh
$: 3$
d. Tidak Berpengaruh
$: 2$
e. Sangat Tidak Berpengaruh
$: 1$

\section{Analisis Data}

Analisis data yang digunakan dalam penelitian ini adalah Analisis Regresi Linier Berganda (Multiple Linier Regression).

$\mathrm{Y}=a+b 1 \times 1+b 2 \times 2+b 3 \times 3+e$ 
Dimana :

$\mathrm{Y} \quad=$ Pendapat Petani

$x 1=$ Aspek Ekologi

$x 2=$ Aspek Ekonomi

$x 3=$ Aspek Teknologi

$a \quad=$ Konstanta

$b 1=$ Koofisien regresi $\mathrm{x} 1$

b2 $=$ Koofisien regresi $\mathrm{x} 2$

b3 = Koofisien regresi $\mathrm{x} 3$

$e \quad=$ Standar eror

\section{HASIL DAN PEMBAHASAN}

\section{Responden}

Dalam penelitian ini, pengambilan data dilakukan dengan cara melakukan kuisioner kepada 30 (tiga puluh) responden dari petani Padi Sawah di Kecamatan Modayag.

Table 3. Karakteristik responden

\begin{tabular}{|c|c|}
\hline \multirow{2}{*}{ Uraian } & Jumlah \\
\hline & Responden \\
\hline \multicolumn{2}{|l|}{ Jenis Kelamin } \\
\hline - $\overline{\text { Laki-laki }}$ & $19(63,3 \%)$ \\
\hline - Perempuan & $11(36,6 \%)$ \\
\hline \multicolumn{2}{|l|}{$\underline{\text { Usia (thn) }}$} \\
\hline$-\overline{<25}$ & $6(20 \%)$ \\
\hline$-26-40$ & $15(50 \%)$ \\
\hline$->40$ & $9(30 \%)$ \\
\hline \multicolumn{2}{|l|}{ Pendidikan } \\
\hline$-\overline{\mathrm{SD}}$ & $16(53,3 \%)$ \\
\hline - SLTP & $9(30 \%)$ \\
\hline - SLTA & $5(16 \%)$ \\
\hline \multicolumn{2}{|l|}{ Luas Lahan (ha) } \\
\hline$-\overline{<0,5}$ & $9(30 \%)$ \\
\hline$-0,6-1$ & $16(53,3 \%)$ \\
\hline$->1$ & $5(16,6 \%)$ \\
\hline \multicolumn{2}{|c|}{$\underline{\text { Kepemilikan Lahan }}$} \\
\hline - Hak Milik & $23(76,6 \%)$ \\
\hline - Sewa & $3(10 \%)$ \\
\hline - Pinjam & $4(13,3 \%)$ \\
\hline
\end{tabular}

1. Karakteristik responden dilihat jenis kelamin yaitu laki-laki 19 responden $(63,3 \%)$ perempuan 11 responden $(36,6 \%)$

2. Karakteristik responden dilihat dari Usia responden petani berumur $<25$ Tahun 6 Orang (20\%), 26-40 Tahun 15 Oang (50 $\%)$ dan>40 Tahun 9 Orang( $30 \%$ ).

3. Karakteristik responden dilihat dari pendidikan yaitu 16 responden SD (53,3\%), 9 responden SLTP (30 \%) dan 5 responden SLTA $(16,6 \%)$.
4. Karakteristik responden dilihat dari Luas lahan yaitu 9 responden (30\%)mempunyai luas lahan <0,5Ha, 16 responden $(53,3$ $\%)$ dan 5 responden $(16,6 \%)$ mempunyai luas lahan $>1 \mathrm{Ha}$.

5. Karakteristik responden dilihat dari status kepemilikan lahan yaitu $23 \quad(76,6 \%)$ responden memiliki lahan dengan status Hak Milik, $3(10 \%)$ responden memiliki lahan dengan status di Sewa dan 4 (13,3\%) Responden memiliki lahan dengan status Pinjam.

Dari hasil penelitian yang dilakukan dapat disimpulkan bahwa jumlah laki-laki lebih banyak mengikuti penyuluhan dibandingkan dengan perempuan itu dikarenakan laki-laki lebih aktif dilapangan dan lebih mau belajar tentang Bididaya Tanaman padi sedangkan yang perempuan banyak yang bekerja dirumah sebagai ibu rumah tangga, sedangkan menurut Umur dapat disimpulkan bahwa petani yang berumur 26-40 Tahun yang paling banyak mengikuti penyuluhan dan mengaplikasikanya di lapangan itu di sebabkan karena petani yang berumur antara 26-40 tahun punya keinginan besar untuk mencoba sesuatu yang baru khususnya dalam melakukan budidaya tanaman Padi, Menurut tingkat pendidikan, dapat disimpulkan bahwa pendidikan SD lebih banyak berpropesi sebagai petani itu di karenakan sulitnya mencari pekerjaan lain dengan mengunakan Ijasah SD sehingga banyak mansyarakat yang hanya memiliki Ijasah SD beralih propesi menjadi petani khususnya petani Padi sawah, sedangkan menurut luas dan kepemilikan lahan dapat disimpulkan bahwa petani padi sawah yang ada di kecamatan modayag rata-rata memiliki lahan dengan luas 0,6-1 Ha dengan statu kepemilikan lahan yaitu Hak Milik.

\section{Deskripsi Jawaban Responden}

1. Aspek Ekologi

a) Pendapat 30 Responden dari Aspek Lingkungan dapat dilihat pada tabel dibawah ini:

Tabel 4. Frekuensi jawaban responden

\begin{tabular}{|c|c|c|c|}
\hline & & Frequency & Persentase \\
\hline \multirow[t]{3}{*}{ Valid } & 2.00 & 1 & $3,3 . \%$ \\
\hline & 4.00 & 12 & $40 . \%$ \\
\hline & 5.00 & 17 & $56.7 \%$ \\
\hline Total & & & $100 . \%$ \\
\hline
\end{tabular}


Dari tabel diatas dapat kita lihat bahwa pendapat petani tentang Suhu berpengaru pada Penyuluhan Pertanian dalam Pelestarian Lingkungan pada Petani padi sawah? 1 (satu) Petani atau 3,3\% menjawab tidak Berpengaruh, 12 (dua belas) Petani atau $40 \%$ menjawab Berpengaruh dan 17 (tuju belas) Petani atau $56,7 \%$ menjawab sangat Berpengaruh.

Dari penjelasan di atas dapat disimpulkan bahwa 1 Petani menjawab tidak berpengaruh dan sisanya yaitu 12 Petani dan 17 Petani masing-masing menjawah berpengaruh dan sangat berpengaruh itu dikarenakan 1 Petani yang menjawab tidak berpengaruh itu kurang memperhatikan pengaruh Suhu pada Budidaya tanaman Padi Sawah terutama Fisiologi Tumbuhan antara lain pembukaan stomata, laju trasnpirasi, laju penyerapan air dan nutrisi. Suhu yang terlalu tinggi atau terlalu rendah akan menghambat proses pertumbuhan. Suhu yang paling baik untuk tanaman Padi Sawah yaitu $15^{\circ} \mathrm{C}-30^{\circ} \mathrm{C}$.

b) Pendapat 30 Responden dari Aspek Lingkungan dapat dilihat pada tabel dibawah ini:

Tabel 5. Frekuensi jawaban responden

\begin{tabular}{rrrr}
\hline & & Frequency & Persentase \\
\hline Valid 2.00 & 1 & $3,3 . \%$ \\
& 4.00 & 13 & $43,3 \%$ \\
& 5.00 & 16 & $53,3 \%$ \\
\hline Total & & 30 & $100 . \%$ \\
\hline
\end{tabular}

Dari tabel diatas dapat kita lihat bahwa pendapat petani tentang Kelembaban berpengaru pada Penyuluhan Pertanian dalam Pelestarian Lingkungan pada Petani padi sawah? 1 (satu) Petani atau 3,3\% menjawab tidak berpengaruh, 13 (tiga belas) Petani atau 43,3\% menjawab berpengaruh dan 16 (enam belas) Petani atau 53,3 $\%$ menjawab sangat berpengaruh.

Dari penjelasan di atas dapat disimpulkan bahwa 1 Petani menjawab tidak berpengaruh dan sisanya yaitu 13 Petani dan 16 Petani masingmasing menjawah berpengaruh dan sangat berpengaruh itu dikarenakan 1 Petani yang menjawab tidak berpengaruh itu kurang memperhatikan pengaruh Kelembaban pada Budidaya tanaman Padi Sawah. kelembaban sangat erat kaitanya dengan laju tarspirasi melalui daun karena transpirasi akan terkait dengan laju pengangkutan air dan unsur kara terlarut. Jika kondisi lembab dapat di pertahankan maka banyak air yang diserap dan lebih sedikit yang di uapkan.

c) Pendapat 30 Responden dari Aspek Lingkungan dapat dilihat pada tabel

dibawah ini:

Tabel 6. Frekuensi jawaban responden

\begin{tabular}{rrrr}
\hline & & Frequency & Persentase \\
\hline Valid & 2.00 & 2 & $6,7 \%$ \\
& 4.00 & 13 & $43,3 \%$ \\
& 5.00 & 15 & $50 \%$ \\
\hline Total & & 30 & $100 . \%$ \\
\hline
\end{tabular}

Dari tabel diatas dapat kita lihat bahwa pendapat petani tentang Angin berpengaru pada Penyuluhan Pertanian dalam Pelestarian Lingkungan pada Petani padi sawah? 2 (Dua) Petani atau 6,7\% menjawab tidak Berpengaruh, 13 (tiga belas) Petani atau 43,3\% menjawab Berpengaruh dan 15 (lima belas) Petani atau 50 $\%$ menjawab sangat Berpengaruh.

Dari penjelasan di atas dapat disimpulkan bahwa 2 Petani menjawab tidak berpengaruh dan sisanya yaitu 13 Petani dan 15 Petani masingmasing menjawah berpengaruh dan sangat berpengaruh itu dikarenakan 2 Petani yang menjawab tidak berpengaruh itu kurang memperhatikan pengaruh Angin pada Budidaya tanaman Padi Sawah terutama dalam penyerbukan (lebih-lebih penyerbukan silang) selain itu angin dapat mengatur penguapan dan membawa uap air sehingga udara panas menjadi sejuk serta membawa gas-gas yang sangat dibutuhkan oleh tanaman Padi sawah.

d) Pendapat 30 Responden dari Aspek Lingkungan dapat dilihat pada tabel dibawah ini:

Tabel 7. Frekuensi jawaban responden

\begin{tabular}{rrcr}
\hline & & Frequency & Persentase \\
\hline Valid & 2.00 & 1 & $3,3 \%$ \\
& 4.00 & 7 & $23,3 \%$ \\
& 5.00 & 22 & $73,3 \%$ \\
\hline Total & & 30 & $100 . \%$ \\
\hline
\end{tabular}

Dari tabel diatas dapat kita lihat bahwa pendapat petani tentang Tanah berpengaru pada Penyuluhan Pertanian dalam Pelestarian Lingkungan pada Petani padi sawah? 1 (satu) Petani atau 3,3\% menjawab tidak berpengaruh, 7 (tujuh) Petani atau 23,3\% menjawab berpengaruhdan 22 (dua puluh dua) Petani atau $73,3 \%$ menjawab sangat berpengaruh. 
Dari penjelasan di atas dapat disimpulkan bahwa 1 Petani menjawab tidak berpengaruh dan sisanya yaitu 7 Petani dan 22 Petani masing-masing menjawah berpengaruh dan sangat berpengaruh itu dikarenakan 1 Petani yang menjawab tidak berpengaruh itu kurang memperhatikan pengaruh Tanah pada Budidaya tanaman Padi Sawah padahal tanah merupakan tempat berpegang dan pertumpuk untuk tegaknya tanaman selain itu tanah juga merupakan media dari unsur-unsur meneral yang dibutuhkan oleh tanaman padi sawah.

e) Pendapat 30 Responden dari Aspek Lingkungan dapat dilihat pada tabel dibawah ini:

Tabel 8. Frekuensi jawaban responden

\begin{tabular}{rcrr}
\hline & Frequency & Persentase \\
\hline Valid 2.00 & 1 & $3,3 \%$ \\
3.00 & 2 & $6,7 \%$ \\
4.00 & 9 & $30 \%$ \\
& 5.00 & 18 & $60 \%$ \\
\hline Total & & 30 & $100 \%$ \\
\hline
\end{tabular}

Dari tabel diatas dapat kita lihat bahwa pendapat petani tentang Cahaya berpengaru pada Penyuluhan Pertanian dalam Pelestarian Lingkungan pada Petani padi sawah? 1 (satu) Petani atau 3,3\% menjawab tidak Berpengaruh, 2 (dua) Petani atau 6,7 \% menjawab kurang Berpengaruh, 9 (sembilan) Petani atau $30 \%$ menjawab Berpengaruhdan 18 (delapan belas) Petani atau $60 \%$ menjawab sangat Berpengaruh.

Dari penjelasan di atas dapat disimpulkan bahwa 1 Petani menjawab tidak berpengaruh 2 Petani menjawab kurang berpengaruh dan sisanya yaitu 9 Petani dan 18 Petani masing-masing menjawah berpengaruh dan sangat berpengaruh itu dikarenakan 3 responden/petani yang menjawab tidak berpengaruh dan kurang berpengaruh itu kurang memperhatikan pengaruh Cahaya pada Budidaya tanaman Padi Sawah terutama pada proses fotosintesis tanaman yang kekurangan penyinaran cahaya terutama cahaya matahari akan mengalami gejala Etiolasi dimana batang kecambah akan tumbuh lebih cepat namun lemah dan daunnya berukuran lebih kecil, tipis serta pucat.
2. Aspek Ekonomi

a) Pendapat 30 Responden dari Aspek Ekonomi dapat dilihat pada tabel dibawah ini:

Tabel 9. Frekuensi jawaban responden

\begin{tabular}{|c|c|c|}
\hline & Frequency & Persentase \\
\hline Valid 3.00 & 1 & $3,3 \%$ \\
\hline 4.00 & 18 & $60 \%$ \\
\hline 5.00 & 11 & $36,7 \%$ \\
\hline Total & 30 & $100 . \%$ \\
\hline
\end{tabular}

Dari tabel diatas dapat kita lihat bahwa pendapat petani tentang Modal berpengaru pada Penyuluhan Pertanian dalam Pelestarian Lingkungan pada Petani padi sawah? 10 (sepuluh) Petani atau 33,3\% menjawab kurang berpengaruh, 14 (empat belas) Petani atau 46,7 $\%$ menjawab berpengaruh dan 6 (enam) Petani atau $20 \%$ menjawab sangat berpengaruh.

Dari penjelasan di atas dapat disimpulkan bahwa 10 Petani menjawab tidak berpengaruh dan sisanya yaitu 14 Petani dan 6 Petani masing-masing menjawah berpengaruh dan sangat berpengaruh itu dikarenakan 10 responden/petani yang menjawab Modal tidak berpengaruh itu suda tergolong dalam petani kaya atau petani komersil yang suda memiliki lahan sawah di atas $1 \mathrm{Ha}$. Akan tetapi yang sisanya yaitu 20 responden/petani yang menjawab berpengaruh dan sangat berpengaruh ini tergolong dalam petani kecil atau petani tidak berkomersil sehingga modal merupakan faktor yang sangat penting dalam usaha pertanian terutama tanaman padi sawah karena dengan keterbatasan modal tersebut akan menyebabkan petani banyak meminjam modal pada rentenir dan pengijon.

b) Pendapat 30 Responden dari Aspek Ekonomi dapat dilihat pada tabel dibawah ini:

\section{Tabel 10. Frekuensi jawaban responden}

\begin{tabular}{cccr}
\hline & Frequency & Persentase \\
\hline Valid 3.00 & 8 & $26,7 \%$ \\
& 4.00 & 19 & $63,3 \%$ \\
& 5.00 & 3 & $10 \%$ \\
\hline Total & 30 & $100 . \%$ \\
\hline
\end{tabular}

Dari tabel diatas dapat kita lihat bahwa pendapat petani tentang Biaya Saprodi berpengaru pada Penyuluhan Pertanian dalam Pelestarian Lingkungan pada Petani padi sawah? 8 (delapan) Petani atau 26,7 \% menjawab kurang berpengaruh, 19 (sembilan 
belas) Petani atau 63,3 \% menjawab berpengaruh dan 3 (tiga) Petani atau $10 \%$ menjawab sangat perpengaruh.

Dari penjelasan di atas dapat disimpulkan bahwa 8 Petani menjawab tidak berpengaruh dan sisanya yaitu 19 Petani dan 3 Petani masing-masing menjawah berpengaruh dan sangat berpengaruh itu dikarenakan 8 Petani yang menjawab biaya saprodi tidak berpengaruh itu dikarenakan 8 Petani suda menyiapkan biaya sarana produksi sendiri seperti Beni, Pupuk, Pestisida dan lain-lain sementara 22 Petani yang menjawab berpengaruh dan sangat berpengaruh ini belum menyediakan sarana produksi terlebih dahuluh sehingga dalam melakukan budidaya tanaman padi sawah biaya produksi sangat berpengaruh dalam keberhasilan patani padi sawah.

c. Pendapat 30 Responden dari Aspek Ekonomi dapat dilihat pada tabel dibawah ini :

Tabel 11. Frekuensi jawaban responden

\begin{tabular}{|c|c|c|}
\hline & Frequency & Persentase \\
\hline Valid 3.00 & 7 & $23,3 \%$ \\
\hline 4.00 & 17 & $56,7 \%$ \\
\hline 5.00 & 6 & $20 \%$ \\
\hline Total & 30 & $100 . \%$ \\
\hline
\end{tabular}

Dari tabel diatas dapat kita lihat bahwa pendapat petani tentang Biaya Pengolahan berpengaru pada Penyuluhan Pertanian dalam Pelestarian Lingkungan pada Petani padi sawah? 7 (tuju) Petani atau 23,3 \% menjawab kurang Berpengaruh, 17 (tuju belas) Petani atau $56,7 \%$ menjawab berpengaruh dan 6 (enam) Petani atau 20\% menjawab sangat berpengaruh.

Dari penjelasan di atas dapat disimpulkan bahwa 7 Petani menjawab tidak berpengaruh dan sisanya yaitu 17 Petani dan 6 Petani masing-masing menjawah berpengaruh dan sangat berpengaruh itu dikarenakan 7 Petani yang menjawab biaya pengolahan tidak berpengaruh dikarenakan 7 Petani hanya memiliki lahan yang kecil yaitu $<0,5 \mathrm{Ha}$ serta mengolah lahan pertanianya sendiri dan tidak membayar buru tani sehingga menguranggi biaya pengolahan sementara 23 responden/petani yang menjawah berpengaruh dan sangat berpengaruh itu mempunyai lahan yang lebih luas sehingga memerlukan buru tani tambahan dalam melakukan budidaya tanaman padi sawah. d. Pendapat 30 Responden dari Aspek Ekonomi dapat dilihat pada tabel dibawah ini :

Tabel 12. Frekuensi jawaban responden

\begin{tabular}{|c|c|c|c|}
\hline & Frequency & Persentase \\
\hline \multirow[t]{3}{*}{ Valic } & 3.00 & 4 & $13,3 \%$ \\
\hline & 4.00 & 18 & $60 \%$ \\
\hline & 5.00 & 8 & $26,7 \%$ \\
\hline Total & & 30 & $100 . \%$ \\
\hline
\end{tabular}

Dari tabel diatas dapat kita lihat bahwa pendapat petani tentang Biaya panen dan pasca panen berpengaru pada Penyuluhan Pertanian dalam Pelestarian Lingkungan pada Petani padi sawah? 4 (empat) Petani atau 13,3\% menjawab kurang berpengaruh, 18 (Delapan belas) Petani atau $60 \%$ menjawab berpengaruh dan 8 (delapan) Petani atau 26,7\% menjawab sangat berpengaruh.

Dari penjelasan di atas dapat disimpulkan bahwa 4 Petani menjawab tidak berpengaruh dan sisanya yaitu 18 Petani dan 8 Petani masing-masing menjawah berpengaruh dan sangat berpengaruh itu dikarenakan 4 Petani yang menjawab biaya panen tidak berpengaruh dikarenakan 4 Petani suda memiliki alsintan (alat dan mesin pertanian) yang digunakan dalam pengolahan panen dan pasca panen sementara 26 Petani yang menjawah berpengaruh dan sangat berpengaruh iyu belum memiliki alsintan sehingga masi menyewa dari petani lain.

\section{Aspek Teknologi}

a. Pendapat 30 Responden dari Aspek Teknologi dapat dilihat pada tabel dibawah ini :

Tabel 13. Frekuensi jawaban responden

\begin{tabular}{cccc}
\hline & Frequency & Persentase \\
\hline Valid & 3.00 & 1 & $3,3 \%$ \\
& 4.00 & 18 & $60 \%$ \\
& 5.00 & 11 & $36,7 \%$ \\
\hline Total & 30 & $100 . \%$ \\
\hline
\end{tabular}

Dari tabel diatas dapat kita lihat bahwa pendapat petani tentang Pestisida Nabati berpengaru pada Penyuluhan Pertanian dalam Pelestarian Lingkungan pada Petani padi sawah? 1 (satu) Petani atau 3,3\% menjawab kurang berpengaruh, 18 (delapan belas) Petani atau $60 \%$ menjawab berpengaruh dan 11 (sebalas) Petani atau 36,7\% menjawab sangat berpengaruh. 
Dari penjelasan di atas dapat disimpulkan bahwa 1 Petani menjawab tidak berpengaruh dan sisanya yaitu 18 Petani dan 11 Petani masing-masing menjawah berpengaruh dan sangat berpengaruh sementara 1 Petani yang menjawab Pestisida Nabati tidak berpengaruh bagi tanaman,lingkungan dan kesehatan manusia belum memahami manfaat pestisida nabati serta masi sering mengunakan pestisida kimia dalam membudidayakan tanaman padi. sementara 29 Petani suda mengunakan pestisida Nabati dalam melakukan budidaya tanaman padi karena suda memahami manfaat dari pestisida nabati baik untuk tanaman, lingkungan dan kesehatan manusia.

b. Pendapat 30 Responden dari Aspek Teknologi dapat dilihat pada tabel dibawah ini :

Tabel 14. Frekuensi jawaban responden

\begin{tabular}{|c|c|c|c|}
\hline & & Frequency & Persentase \\
\hline \multirow[t]{3}{*}{ Valid } & 3.00 & 1 & $3,3 \%$ \\
\hline & 4.00 & 16 & $53,3 \%$ \\
\hline & 5.00 & 13 & $43,3 \%$ \\
\hline Total & & 30 & $100 . \%$ \\
\hline
\end{tabular}

Dari tabel diatas dapat kita lihat bahwa pendapat petani tentang Pupuk Organik berpengaru pada Penyuluhan Pertanian dalam Pelestarian Lingkungan pada Petani padi sawah? 1 (satu) Petani atau 3,3 \% menjawab tidak berpengaruh, 16 (enam belas) Petani atau $53,3 \%$ menjawab berpengaruh dan 13 (tiga belas) Petani atau 43,3\% menjawab sangat berpengaruh.

Dari penjelasan di atas dapat disimpulkan bahwa 1 Petani menjawab tidak berpengaruh dan sisanya yaitu 16 Petani dan 13 Petani masing-masing menjawah berpengaruh dan sangat berpengaruh sementara 1 Petani yang menjawab Pupuk Organik tidak berpengaruh bagi tanaman, lingkungan dan kesehatan manusia belum memahami manfaat pupuk organik serta masi sering mengunakan pupuk kimia dalam membudidayakan tanaman padi. sementara 29 Petani suda mengunakan pupuk organik dalam melakukan budidaya tanaman padi karena suda memahami manfaat dari pupuk organik baik untuk tanaman, lingkungan dan kesehatan manusia. c. Pendapat 30 Responden dari Aspek Teknologi dapat dilihat pada tabel dibawah ini

Tabel 15. Frekuensi jawaban responden

\begin{tabular}{|c|c|c|}
\hline & Frequency & Persentase \\
\hline Valid 3.00 & 1 & $3,3 \%$ \\
\hline 4.00 & 17 & $56,7 \%$ \\
\hline 5.00 & 12 & $40 \%$ \\
\hline Total & 30 & $100 . \%$ \\
\hline
\end{tabular}

Dari tabel diatas dapat kita lihat bahwa pendapat petani tentang cara tanam Jajar Legowo berpengaru pada Penyuluhan Pertanian dalam Pelestarian Lingkungan pada Petani padi sawah? 1 (satu) Petani atau 3,3\% menjawab kurang berpengaruh, 17 (tuju belas) Petani atau $56,7 \%$ menjawab berpengaruh dan 12 (dua belas) Petani atau $40 \%$ menjawab sangat berpengaruh.

Dari penjelasan di atas dapat disimpulkan bahwa 1 Petani menjawab tidak berpengaruh dan sisanya yaitu 17 Petani dan 12 Petani masingmasing menjawah berpengaruh dan sangat berpengaruh sementara 1 Petani yang menjawab sistim tanam Jarwo tidak berpengaruh bagi tanaman itu dikarenakan 1 Petani kurang memperhatikan julah populasi yang bertambah sekitar 20-30 \% /Ha serta dengan adanya baris kosong akan mempermuda perawatan baik penyiangan,pemupukan dan penyemprotan serta menguranggi kemungkinan serangan hama dan penyakit sementara 29 Petani suda memahami manfaat dari tanaman padi dengan sitem tandur jajar legowo.

4. Pendapat Petani

a. Pendapat 30 Responden tentang Peran Penyuluhan dan Manfaat Penyuluhan dapat dilihat pada tabel dibawah ini :

Tabel 16. Frekuensi jawaban responden

\begin{tabular}{|c|c|c|}
\hline & Frequency & Persentase \\
\hline Valid 3.00 & 10 & $33,3 \%$ \\
\hline 4.00 & 16 & $53,3 \%$ \\
\hline 5.00 & 4 & $13,3 \%$ \\
\hline Total & 30 & $100 . \%$ \\
\hline
\end{tabular}

Dari tabel diatas dapat kita lihat bahwa pendapat petani tentang Peran Penyuluhan berpengaru pada Penyuluhan Pertanian dalam Pelestarian Lingkungan pada Petani padi sawah? 10 (sepuluh) Petani atau 33,3\% menjawab kurang berpengaruh, 16 (enam belas) Petani atau 53,3\% menjawab berpengaruh dan 4 (empat) Petani atau $13,3 \%$ menjawab sangat berpengaruh. 
b. Pendapat 30 Responden tentang Peran Penyuluhan dan ManfaatPenyuluhan dapat dilihat pada tabel dibawah ini :

Tabel 17. Frekuensi jawaban responden

\begin{tabular}{|c|c|c|}
\hline & Frequency & Persentase \\
\hline Valid 3.00 & 11 & $36,7 \%$ \\
\hline 4.00 & 9 & $30 \%$ \\
\hline 5.00 & 10 & $33,3 \%$ \\
\hline Total & 30 & $100 . \%$ \\
\hline
\end{tabular}

Dari tabel diatas dapat kita lihat bahwa pendapat petani Manfaat Penyuluhan berpengaru pada Penyuluhan Pertanian dalam Pelestarian Lingkungan pada Petani padi sawah? 11 (sebelas) Petani atau 36,7 \% menjawab kurang berpengaruh, 9 (sembilan) Petani atau $30 \%$ menjawab berpengaruh dan 10 (sepuluh) Petani atau 33,3\% menjawab sangat berpengaruh.

\section{Persamaan Regresi Linier Berganda}

Mencari persamaan regresi berganda, terlebih dahulu menghitung koefisien-koefisien regresi dengan mencari penggandaan suatu variabel dengan variabel yang lain.Dengan koefisien-koefisien yang didapat dari perhitungan lampiran, yaitu untuk perlakuan pada rumusan permasalahan dan hipotesis, maka didapat persamaan regresi linier berganda seperti pada Tabel 18 hasil analisis regresi berganda.

Diperoleh persamaan regresinya :

$\mathrm{Y}=\mathrm{a}+\beta \mathrm{X}_{1}+\beta \mathrm{X}_{2}+\beta \mathrm{X}_{3}+\mathrm{e}$

$\mathrm{Y}=1,746+0,010 \mathrm{X}_{1}+0,392 \mathrm{X}_{2}+0,031 \mathrm{X}_{3}+\mathrm{e}$

a. Konstanta $\mathrm{a}=1,746$

Artinya jika aspek Lingkungan, Ekonomi, dan Teknologi nilainya 0 (nol) maka pendapat petani tentang pengaruh penyuluh nilainya sebesar 1,746

b. Parameter $\beta X_{1}=0,010$

Artinya jika aspek Lingkungan ditingkatkan sebesar 1 satuan, maka pendapat petani tentang pengaruh penyuluh akan naik sebesar 0,010 satuan

c. Parameter $\beta X_{1}=0,392$

Artinya jika aspek ekonomi ditingkatkan sebesar 1 satuan, maka pendapat petani tentang pengaruh penyuluh akan naik sebesar 0,392 satuan

d. Parameter $\beta X_{1}=0,031$

Artinya jika aspek teknologi ditingkatkan sebesar 1 satuan, maka pendapat petani tentang pengaruh penyuluh akan naik sebesar 0,031 satuan

\section{Koefisien Determinasi}

Menganalisa dan mengetahui seberapa besar pengaruh faktor-faktor yang mempengaruhi peendapat petani tentang pengaruh penyuluh, maka dapat dilihat pada Tabel 19 Uji Koefisien Determinasi.

Uji $R^{2}$ digunakan untuk mengukur seberapa besar variasi (jumlah kuadrat simpangan suatu variabel dari nilai rata-ratanya) dari variabel terikat dapat dijelaskan oleh variabel besarnya dalam modal regresi, sehingga dapat mengetahui kecocokan model regresi tersebut (goodness of fit).

Tabel Model Sumary diatas dapat diketahui bahwa nilai $\mathrm{R}^{2}$ adalah 0,502 . Jadi sumbangan pengaruh dari variabel independen yaitu sebesar $50,2 \%$ sedangkan sisanya sebesar $49,8 \%$ dipengaruhi oleh faktor yang tidak diteliti.

\section{Pengujian Hipotesis}

a. Uji F-Statistik aspek ekologi $\left(\mathrm{X}_{1}\right)$

Uji F-Statistik digunakan untuk mengetahui apakah variabel bebas yakni aspek Teknologi $\left(\mathrm{X}_{1}\right)$, aspek Ekonomi $\left(\mathrm{X}_{2}\right)$, dan aspek Teknologi $\left(\mathrm{X}_{3}\right)$ berpengaruh secara bersamasama terhadap variabel terikat yakni pendapat petani tentang penyuluh (Y). Dapat dilihat pada Tabel 20. Analusis of variance.

Prosedur Pengujian uji F Statistik adalah sebagai berikut

1. Menentukan hipotesis nol dan hipotesis alternatif

$H_{0}: \beta X_{1} \neq \beta X_{2} \neq \beta X_{3} \neq 0$

Artinya aspek Lingkungan, aspek Ekonomi dan aspek Teknologi secara bersama-sama tidak berpengaruh terhadap pendapat petani tentang penyuluh.

$H_{a}: \beta X_{1} \neq \beta X_{2} \neq \beta X_{3} \neq 0$

Artinya aspek Lingkungan, aspek Ekonomi, dan aspek Teknologi secara bersama-sama berpengaruh terhadap pendapat petani tentang penyuluh.

2. Menentukan taraf signifikan

Taraf signifikan menggunakan 0,05

3. Menentukan F hitung dan F tabel

- F hitung adalah 8,730 (lihat pada tabel ANOVA)

- F tabel diperoleh dari tabel statistic pada signifikasi $0,05 \mathrm{df} 1=\mathrm{k}-1$ atau $4-1=3$, dan df $2=n-k$ atau $30-4=26$ ( $\mathrm{k}$ adalah jumlah variabel) 
Cara lain mencari $F$ tabel yaitu menggunakan program Ms Excel dengan cara mengetik FINV $(0,05,3,26)$ pada cell yang kosong kemudian tekan enter. Sehingga nilai $\mathrm{F}$ tabel diperoleh 2,975

4. Pengambilan Keputusan

$\mathrm{F}$ hitung $\leq \mathrm{F}$ tabel jadi $\mathrm{H}_{0}$ diterima

$\mathrm{F}$ hitung $>\mathrm{F}$ tabel jadi $\mathrm{H}_{0}$ ditolak

5. Kesimpulan

Dapat diketahui nilai $\mathrm{F}$ Hitung 8,730 > F tabel sebesar 2,975, jadi hipotesis nol ditolak artinya aspek ekologi, aspek ekonomi dan aspek teknologi secara bersama-sama berpengaruh terhadap pendapat petani tentang penyuluh

\section{b. Uji t}

Uji t-Statistik merupakan pengujian untuk mengetahui apakah variabel bebas yakni aspek ekologi $\left(\mathrm{X}_{1}\right)$, aspek ekonomi $\left(\mathrm{X}_{2}\right)$, dan aspek teknologi $\left(\mathrm{X}_{3}\right)$ secara individu (parsial) mempunyai pengaruh yang signifikan terhadap pendapat petani tentang penyuluh (Y).

berikut :

Prosedur pengajuannya adalah sebagai

Pengujian aspek ekologi $\left(\mathrm{X}_{1}\right)$

1. Menentukan hipotesis nol dan hipotesis alternatif

$\mathrm{H}_{0}=\mathrm{X}_{1}=0$

Artinya aspek ekologi tidak berpengaruh terhadap pendapat petani tentang penyuluh.

$\mathrm{H}_{0} \neq \mathrm{X}_{1} \neq 0$

Artinya aspek ekologi berpengaruh terhadap pendapat petani tentang penyuluh.

2. Menentukan taraf signifikan

Taraf signifikan menggunakan 0,05

3. Menentukan t Hitung dan t Tabel

- t Hitung adalah 3,209 (lihat pada tabel coefficients)

- t Tabel dapat dicari pada tabel statistik pada signifikasi $0,05 / 2=0,025$ (uji 2 sisi) dengan $\mathrm{df}=\mathrm{n}-\mathrm{k}-1$ atau $30-3-1=26(\mathrm{k}=$ jumlah variabel independen), cara lain mencari $t$ tabel yaitu dengan menggunakan program Ms Excel dengan megetik TINV $(0,05,26)$ pada cell yang kosong kemudian tekan enter. Sehingga diperoleh $t$ tabel sebesar 2,005

4. Pengambilan keputusan

$\mathrm{t}$ hitung $\leq \mathrm{t}$ tabel atau $-\mathrm{t}$ hitung $\geq \mathrm{t}$ tabel, jadi $\mathrm{H}_{0}$ diterima

$\mathrm{t}$ hitung $>\mathrm{t}$ tabel atau $-\mathrm{t}$ hitung $<\mathrm{t}$ tabel jadi $\mathrm{H}_{0}$ ditolak
5. Kesimpulan

Pada hasil diatas diperoleh bahwa nilai $\mathrm{t}$ hitung sebesar 3,209 > dari t tabel sebesar 2,055 sehingga hipotesis nol di tolak, artinya aspek ekologi berpengaruh terhadap pendapat petani tentang penyuluh.

c. Pengujian aspek ekonomi $\left(\mathrm{X}_{2}\right)$

1. Menentukan hipotesis nol dan hipotesis alternatif

$\mathrm{H}_{0}=\mathrm{X}_{2}=0$

Artinya aspek ekonomi tidak berpengaruh terhadap pendapat petani tentang penyuluh.

$\mathrm{H}_{0} \neq \mathrm{X}_{2} \neq 0$

Artinya aspek ekonomi berpengaruh terhadap pendapat petani tentang penyuluh.

2. Menentukan taraf signifikan Taraf signifikan menggunakan 0,05

3. Menentukan t Hitung dan $\mathrm{t}$ Tabel

- $\mathrm{t}$ Hitung adalah 4,421 (lihat pada tabel coefficients)

- $\mathrm{t}$ Tabel dapat dicari pada tabel statistik pada signifikasi $0,05 / 2=0,025$ (uji 2 sisi) dengan $\mathrm{df}=\mathrm{n}-\mathrm{k}-1$ atau $30-3-1=26(\mathrm{k}=$ jumlah variabel independen), cara lain mencari $t$ tabel yaitu dengan menggunakan program Ms Excel dengan megetik TINV $(0,05,26)$ pada cell yang kosong kemudian tekan enter. Sehingga diperoleh $t$ tabel sebesar 2,005

4. Pengambilan keputusan

$\mathrm{t}$ hitung $\leq \mathrm{t}$ tabel atau $-\mathrm{t}$ hitung $\geq \mathrm{t}$ tabel, jadi $\mathrm{H}_{0}$ diterima

$\mathrm{t}$ hitung $>\mathrm{t}$ tabel atau $-\mathrm{t}$ hitung $<\mathrm{t}$ tabel jadi $\mathrm{H}_{0}$ ditolak

5. Kesimpulan

Pada hasil diatas diperoleh bahwa nilai $\mathrm{t}$ hitung sebesar 4,421 > dari t tabel sebesar 2,055 sehingga hipotesis nol di tolak, artinya aspek ekonomi berpengaruh terhadap pendapat petani tentang penyuluh.

d. Pengujian aspek teknologi $\left(\mathrm{X}_{3}\right)$

1. Menentukan hipotesis nol dan hipotesis alternatif

$\mathrm{H}_{0}=\mathrm{X}_{3}=0$

Artinya aspek teknologi tidak berpengaruh terhadap pendapat petani tentang penyuluh. $\mathrm{H}_{0} \neq \mathrm{X}_{3} \neq 0$

Artinya aspek teknologi berpengaruh terhadap pendapat petani tentang penyuluh.

2. Menentukan taraf signifikan

Taraf signifikan menggunakan 0,05 
3. Menentukan t Hitung dan t Tabel

- t Hitung adalah 3,293 (lihat pada tabel coefficients)

- t Tabel dapat dicari pada tabel statistik pada signifikasi $0,05 / 2=0,025$ (uji 2 sisi) dengan $\mathrm{df}=\mathrm{n}-\mathrm{k}-1$ atau $30-3-1=26(\mathrm{k}=$ jumlah variabel independen), cara lain mencari $t$ tabel yaitu dengan menggunakan program Ms Excel dengan mngetik TINV $(0,05,26)$ pada cell yang kosong kemudian tekan enter. Sehingga diperoleh $t$ tabel sebesar 2,005

4. Pengambilan keputusan

$\mathrm{t}$ hitung $\leq \mathrm{t}$ tabel atau $-\mathrm{t}$ hitung $\geq \mathrm{t}$ tabel, jadi $\mathrm{H}_{0}$ diterima

$\mathrm{t}$ hitung $>\mathrm{t}$ tabel atau $-\mathrm{t}$ hitung $<\mathrm{t}$ tabel jadi $\mathrm{H}_{0}$ ditolak

5. Kesimpulan

Pada hasil diatas diperoleh bahwa nilai $\mathrm{t}$ hitung sebesar 3,293 > dari t tabel sebesar 2,055 sehingga hipotesis nol di tolak, artinya aspek teknologi berpengaruh terhadap pendapat petani tentang penyuluh.

\section{KESIMPULAN DAN SARAN}

\section{Kesimpulan}

Berdasarkan hasil penelitian analisis

hasil dan pembahasan dapat diambil kesimpulan sebagai berikut:

1. Proses penyuluhan yang di dasari pada Aspek Lingkungan, Aspek Ekonomi dan Aspek Teknologi berpengaruh pada perubahan pengetahuan keterampilan dan sikap petani Padi Sawah di Kecamatan Modayag.

2. Dari ketiga Aspek yang ada yaitu Aspek Lingkungan, Aspek Ekonomi dan Aspek Teknologi yang paling berpengaruh dalam proses penyuluhan pertanian yaitu Aspek Ekonomi.

\section{Saran}

1. Perlu adanya penelitian lanjutan untuk mengetahui pengaruh Penyuluhan Pertanian dari Aspek-aspek yang lain.

2. Penyuluh pertanian di BP3K Modayag sebaiknya lebih meningkatkan peran Penyuluhan terutama pada Aspek Lingkungan dan Aspek Teknologi agar terwujudnya kerangka Segitiga Konsep Pembangunan Berkelanjutan.

\section{DAFTAR PUSTAKA}

Afandi, A.K. 1993. Dasar-Dasar Penelitian Kualitatif.Usaha Nasional. Surabaya.

Arifin, Bustanul. 2008. Strategi Baru Pembangunan Pertanian. http://tkpkri.org/berita/berita/strategibaru-pembangunan-pertanian.html. Diakses pada tanggal 26 Novembar 2015.

Badan Pengembangan Sumber Daya Pertanian. 2009. Modul Pembekaan Bagi THL TB Penyuluh Pertanian. Departemen Pertanian. Jawa Tengah.

Brainy Media. 2009. Definition of Mechanism. http:/www.brainyquote.com /words/me/mechanism188680.html.

Diakses pada tanggal 2 Desembar 2015.

Departemen Pertanian. 2004. Ringkasan Eksekutif Pengkajian 2004. http://www.deptan.go.id/bpsdm/puskaj i/hasil-kajian/ringk_kajian2004.htm.

Diakses pada tanggal 2 Desember 2015.

Departemen Pertanian, 2006. Undang-Undang Republik Indonesia Nomor 16 Tahun 2006 Tentang Sistem Penyuluhan Pertanian, Perikanan dan Kehutanam,Jakarta.

Hadisapoetra, Soedarsono. 1973. Pembangunan Pertanian. Departemen Ekonoi Pertanian Fakultas Pertanian UGM. Yogyakarta.

Hawkins et all. 1982. Agricultural and Livestock Extension Volume 2. Australian University International Development Program. Canberra.

Kartasapoetra, AG. 1991. Teknologi Penyuluhan Pertanian. Radar Jaya Offset. Jakarta.

Mardikanto, Totok. 1994. Bunga Rampai Pembangunan Pertanian. Sebelas Maret University Press. Surakarta.

Mardikanto, Totok, 1993. Penyuluhan Pembangunan Pertanian. Sebelas Maret University Press. Surakarta. 2009. Sistem Penyuluhan Pertanian. Sebelas Maret University Press. Surakarta.

Mardikanto, T dan Arip Wijianto.2005. Modul Kuliah Metoda dan Teknik Penyuluhan Pertanian.Proyek SP4 UNS. Surakarta. 
Menteri Pertanian Republik Indonesia. 2007. Peraturan Menteri Pertanian Nomor: 273/Kpts/OT.160/4/2007 Tentang Pedoman Pembinaan Kelembagaan Petani Lampiran 1 Pedoman Pertumbuhan dan Pengembangan Kelompok Tani dan Gabungan Kelompok Tani.

$\begin{array}{llr}\text { Pertanian } & & \text { Menteri } \\ \text { 273/Kpts/OT.160/4/2007 } & \text { Tomor: } \\ \text { Pedomantang } & \text { Pembinaan } & \text { Kelembagaan } \\ \text { Petani Lampiran 2 } & \text { Pedoman } \\ \text { Penyusunan } & \text { Rencana } & \text { Definitif } \\ \text { Kelompoktani } & \text { (RDK) dan } & \text { Rencana } \\ \text { Definitif } & \text { Kebutuhan Kelompok Tani } \\ \text { (RDKK). } & \text { Departemen r Pertanian. }\end{array}$
Jakarta.

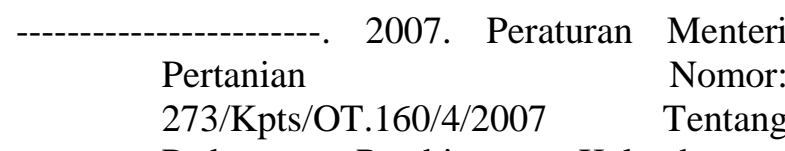
Pedoman Pembinaan Kelembagaan Petani Lampiran 3 Pedoman Sistem Kerja Latihan dan Kunjungan. Departemen Pertanian. Jakarta.

Moleong, L.J. 2001. Metodologi Penelitian Kualitatif. Remaja Rosdakarya. Bandung.

-------------. 2007. Metodologi Penelitian Kualitatif Edisi Revisi. Remaja Rosdakarya. Bandung.

Pearson, Scott et all. 2004. Application of The Policy Analysis Matrix in Indonesian Agriculture. Yayasan Obor Indonesia. Jakarta.

Sastraatmadja, Entang. 1993. Penyuluhan Pertanian. Alumni. Bandung.

Samsudin S, U- 1994.Mangemen Penyuluhan Pertanian. Bina Cipta. Bandung.

Suharto, Edi. 2005.Membangun Masyarakat Memberdayakan Masyarakat. Bandung. PT Refika Aditama.
Setiana, Lucie. 2005. Teknik Penyuluhan dan Pemberdayaan Masyarakat.Ghalia Indonesia. Bogor.

Suhardiyono, L. 1992. Penyuluhan Petunjuk Bagi Penyuluh Pertanian. Erlangga. Jakarta.

Supanggyo. 2007. Buku Penunjang Kuliah Administrasi Penyuluhan Pertanian. Fakultas Pertanian Universitas Sebelas Maret Surakarta.

Sutopo, H B. 2002. Metodologi Penelitian Kualitatif (Dasar Teori dan Terapannya Dalam Penelitian). Sebelas Maret University Press. Surakarta.

Van Den Ban, A.W \& H.S. Hawkins. 1999. Penyuluhan Pertanian. Yogyakarta.Kanisius.

http://ayya-

yy.wordpress.com/2010/05/10/perananpenyuluhan-dalam-pembangunanpertanian-sebagai-upaya-meningkatkankesejahteraan-petani/ (Diakses Pada Tanggal 13 November 2015)

http://idhafarida.wordpress.com/2O12/04/19/defini si-faisafah-dan-peran-penyuluhan-Pertanian/ (Diakses Pada Tanggal 13 November 2015)

http://ardyummagroteknologi.blogspot.com/ (Diakses Pada Tanggal 13 November 2015)

http://serbatani.blogspot.com/2Ol3/O8/skripsiperan-penyuluh-pertaniandalam.html(Diakses Pada Tanggal 13 November 2015)

http://panjaitansumitro.blogspot.com/2012/12/per an-penyuluhan-pertaniandalam.html(Diakses Pada Tanggal 13 November 2015)

http://repository.usu.ac.id/bitstream/123456789/22 005/4/Chapter\%2011.pdf(Diakses Pada Tanggal 26 November 2015)

http://fashihullisantugaspenyuluhan.blogspot.com I (Diakses, Pada Tanggal 26 November 2015) 